\title{
NITROGEN FERTILIZATION OF FALL PANICUM CULTIVARS (Panicum dichotomiflorum Michx.): BIOCHEMICAL AND AGRONOMICAL ASPECTS
}

\author{
Rogério Peres Soratto ${ }^{1 *}$; Eduardo do Valle Lima ${ }^{1}$; Tiago Roque Benetoli da Silva ${ }^{1}$; Carmen \\ Sílvia Fernandes Boaro ${ }^{2}$; Ana Catarina Cataneo ${ }^{3}$ \\ ${ }^{1}$ UNESP/FCA - Depto. de Produção Vegetal, Fazenda Experimental Lageado, s/n, C.P. 237 - 18603-970 - Botucatu, \\ SP - Brasil. \\ ${ }^{2}$ UNESP/IB - Depto. de Botânica, 18618-000 - Botucatu, SP - Brasil. \\ ${ }^{3}$ UNESP/IB - Depto. de Química e Bioquímica. \\ *Corresponding author <soratto@fca.unesp.br>
}

\begin{abstract}
Information on improved fall panicum cultivars and agronomical pratices is scarce because of the relatively small importance of this crop in Brazil. The present study aimed to evaluate levels of nitrogen sidedressing on plant development and biochemical characteristics of two fall panicum cultivars. The experiment was set up under plastic tunnel conditions in Botucatu, São Paulo, Brazil, with plants growing inside asbestos-cement boxes. The experimental design was a randomized block setup and treatments consisted of six levels of nitrogen fertilization $\left(0,40,80,120,160\right.$, and $\left.200 \mathrm{mg} \mathrm{L}^{-1}\right)$ applied at the onset of tillering on two fall panicum cultivars (AL Mogi and AL Tibagi). The application of increasing levels of nitrogen to fall panicum plants increased chlorophyll content, total amino acids, plant dry matter nitrogen content, plant height, tillering and grain yield, and decreased plant dry matter sugar content. The cultivars had similar performances in relation to the evaluated variables, as a response to nitrogen sidedressing.

Key words: nitrogen, sidedressing fertilization, mineral nutrition

\section{ADUBAÇÃO NITROGENADA E ATRIBUTOS BIOQUÍMICOS E AGRONÔMICOS DE CULTIVARES DE PAINÇO (Panicum dichotomiflorum Michx.)}

\begin{abstract}
RESUMO: São escassas as informações sobre cultivares melhoradas e técnicas culturais adequadas à cultura do painço. Este experimento objetivou avaliar o efeito da aplicação de níveis de nitrogênio (N) em cobertura no desenvolvimento e nos atributos bioquímicos de duas cultivares de painço. Para tanto, instalou-se um experimento em Botucatu (SP), em caixas de cimento amianto, mantidas em túnel plástico. O delineamento experimental foi em blocos casualizados, em esquema fatorial 2x6, com dois cultivares de painço (AL Mogi e AL Tibagi) e seis níveis de adubação nitrogenada $\left(0,40,80,120,160\right.$ e $\left.200 \mathrm{mg} \mathrm{L}^{-1}\right)$, aplicada em cobertura, no início do perfilhamento. Os dois cultivares utilizados tiveram comportamento semelhante em relação às variáveis avaliadas, em resposta à aplicação de $\mathrm{N}$ em cobertura. A aplicação de doses de $\mathrm{N}$ na cultura do painço proporcionou incrementos nos teores relativos de clorofila, aminoácidos totais, nitrogênio total e altura das plantas, e redução dos teores de açúcares na matéria seca, até o intervalo entre 120 e $160 \mathrm{mg} \mathrm{de} \mathrm{N} \mathrm{L}^{-1}$. O perfilhamento e produção de grãos tiveram aumento linear com a aplicação de N. A adubação nitrogenada não afetou a produção de matéria seca.

Palavras-chave: nitrogênio, adubação de cobertura, nutrição mineral
\end{abstract}

\section{INTRODUCTION}

Fall panicum (Panicum dichotomiflorum Michx.) is an annual grass, grown for grains, which are utilized as animal feed (Furuhashi, 1995), especially for birds in captivity. It is also used by the beer industry, mixed in small proportion to barley. Little known in Brazil and with a reduced economic expression, when compared to traditional crops, fall panicum is being tested as a soil cover crop species in the no-till system (Lima et al., 2000), and could become a crop option during the relay crop season and in the spring-summer period. However, for this plant to become a soil cover crop it is necessary to increase its straw and grain productivities, which can be achieved by the use of adequate cultural practices.

Maximum productivity depends on environmental factors, such as temperature, solar radiation and mineral nutrition, as well as on genotype and cultural practices (Maman et al., 1999). Therefore, nutrient supply is crucial to obtain high productivities (Clark, 1990), especially in relation to $\mathrm{N}$, in general the most required element by plants (Malavolta, 1979; Maman et al., 1999). 
When plants show deficiency of this element, they become stunted and their leaves assume a coloration between pale green and yellow. Nitrogen sidedressing, in addition to supplying all crop requirements, increases productivity (Oliveira et al., 1996).

Crops such as millet, rice, maize and bean, which usually respond well to nitrogen sidedressing (Costa et al., 1983; Maman et al., 1999; Silva et al., 1999; 2000; Ferreira et al., 2001; Soratto et al., 2000; 2001). Even though no reports evaluating fall panicum were found in the literature, this could also be a species that is responsive to $\mathrm{N}$.

$\mathrm{N}$ is absorbed by the roots, especially in the form of $\mathrm{NO}_{3}^{-}$, and is translocated to the leaves, where it is reduced and incorporated into amino acids (Nelson \& Cox, 2000). The process of reduction causes great energy expenditure to cells. Great part of this process takes place in leaves, which are responsible for the absorption and storage of light energy during photosynthesis. However, part of the reduction occurs in the root, at the expense of energy from carbohydrates produced in the leaves (Malavolta et al., 1997). In addition, plants utilize carbon skeletons of sugars for amino acid synthesis (Turley $\&$ Ching, 1986). The biosynthetic pathways of amino acids and nucleotides share nitrogen requirements; however, the soluble, biologically useful compounds of this element are scarce in natural environments (Nelson \& Cox, 2000), hence the need for sidedressing supplementation.

Since fall panicum is a little-known crop in Brazil, it is necessary to develop improved cultivars and adequate cropping techniques. Therefore, this work had the objective of evaluating the effect of application of different levels of $\mathrm{N}$ sidedressing on the development and biochemical attributes of two fall panicum cultivars.

\section{MATERIAL AND METHODS}

The experiment was installed in March, 2002, in a plastic tunnel, in Botucatu, SP, Brazil, (22 $53^{\circ} 09^{\prime \prime} \mathrm{S}, 48^{\circ}$ $26^{\prime} 42$ '"W; altitude of $740 \mathrm{~m}$ ), in asbestos cement boxes of $50 \mathrm{~L}$ capacity, with $30 \mathrm{~cm}$ effective depth and a hole on the bottom to drain the excess water, filled with a medium-textured Oxisol. The chemical characteristics of the soil are: $2 \mathrm{mg} \mathrm{dm}^{-3}$ phosphorus; $23 \mathrm{~g} \mathrm{dm}^{-3}$ organic matter; $\mathrm{pH}$ in $\mathrm{CaCl}_{2}\left(0.01 \mathrm{~mol} \mathrm{~L}^{-1}\right)=4.7 ; 0.1 ; 6 ; 7 ; 34 ; 13$ and $48 \mathrm{mmol}_{\mathrm{c}} \mathrm{dm}^{-3}$ of $\mathrm{K}, \mathrm{Ca} ; \mathrm{Mg}, \mathrm{H}+\mathrm{Al}, \mathrm{BS}$, and $\mathrm{CEC}$, respectively, and $\mathrm{V} \%=28$, according to methodology described in Raij et al. (2001).

The preparation of each box, before filling, consisted of preparing a mixture of soil and $62 \mathrm{~g}$ dolomitic lime (TNP $=90 \%$ ) to raise base saturation to $70 \%$, plus $5 \mathrm{mg} \mathrm{L}^{-1} \mathrm{~N}$ (urea), $150 \mathrm{mg} \mathrm{L}^{-1} \mathrm{P}_{2} \mathrm{O}_{5}$ (single superphosphate), $150 \mathrm{mg} \mathrm{L}^{-1} \mathrm{~K}_{2} \mathrm{O}, 1 \mathrm{mg} \mathrm{L}^{-1} \mathrm{~B}$ (boric acid), and $5 \mathrm{mg} \mathrm{L}^{-1} \mathrm{Zn}$ as basic fertilization. The boxes were then filled, leveled, and moistened until approximately $80 \%$ of the container water capacity, and were then covered with a plastic tarp, remaining under wet incubation for 21 days. After this period, at seeding time, the soil presented the following chemical characteristics: $88 \mathrm{mg} \mathrm{dm}^{-3}$ $\mathrm{P} ; 20 \mathrm{~g} \mathrm{dm}^{-3}$ O.M.; $\mathrm{pH} \mathrm{CaCl}\left(0.01 \mathrm{~mol} \mathrm{~L}^{-1}\right)=5.4 ; 2.2$; $37 ; 16 ; 22 ; 55$ and $77 \mathrm{mmol}_{\mathrm{c}} \mathrm{dm}^{-3} \mathrm{~K}, \mathrm{Ca}, \mathrm{Mg}, \mathrm{H}+\mathrm{Al}, \mathrm{BS}$, and CEC, respectively, and $\mathrm{V} \%=71$.

The experimental was set up in a randomized blocks design, in a $2 \times 6$ factorial scheme, with two fall panicum cultivars, AL Mogi and AL Tibagi, and six levels of nitrogen fertilization: $0,40,80,120,160$, and 200 $\mathrm{mg} \mathrm{L}^{-1}$. Seeding was performed on April 9, 2002, sowing 12 seeds per box. Thinning was performed after seedling emergence, three days after seeding, leaving nine plants per box.

The cycles of the utilized cultivars last from 60 to 80 days, so they can be sown during the regular cropping season, from September to December, or during the relay crop season, from January to March. As a major morphological difference, cultivar AL Mogi has open panicles, while those of AL Tibagi are closed. Sidedressing was performed 25 days after emergence (DAE), at the onset of tillering of the fall panicum plants.

Irrigations were made by means of watering cans, with a watering interval of two days. Emerged weeds were controlled by hand and pest control was performed with one spray of deltamethrin insecticide at $25 \mathrm{DAE}$.

When plants were at full bloom (44 DAE), the chlorophyll content and plant height were determined. Plants were then harvested for biochemical and physiological determinations: relative chlorophyll content, urease activity, total amino acid content, total sugars and reducing sugars contents, total $\mathrm{N}$ content and dry mass in the above-ground part of the plant. The relative chlorophyll content was evaluated by means of a portable Chlorophyll Meter (Minolta, 1989), model SPAD-502 (Soil and Plant Analysis Development), in ten samples per box, in the middle of the flag leaf.

The flag leaf of one plant per pot at full bloom was collected for urease activity determination. Samples (200 $\mathrm{mg}$ ) were cut into small fragments and transferred to a test tube containing a reaction mixture at $30^{\circ} \mathrm{C}$ for 60 minutes (Hogan et al., 1983). Aliquots were extracted from each mixture to determine the amount of ammonia produced in the reaction by the indophenol method (Weatherburn, 1967). Urease activity was expressed as $\mu \mathrm{g}$ of $\mathrm{NH}_{3}$ formed from urea, per gram of fresh leaf tissue per minute.

Also at full bloom, two plants per pot were collected and packaged inside paper bags, properly identified, and dried in a forced aeration oven at a mean temperature of $60-70^{\circ} \mathrm{C}$, until constant weight, and later, ground in a Willey-type mill to determine total amino acids, nitrogen content, total soluble sugars, and reducing sugars. Total amino acids were extracted from dry mass samples with $80 \%$ ethanol at a temperature of $85^{\circ} \mathrm{C}$. Next, 
$0.2 \mathrm{~mL}$ of the extract and $0.4 \mathrm{~mL}$ of ninhydrin reagent were utilized, at a temperature of $85^{\circ} \mathrm{C}$, according to Kabat \& Mayer (1967). The absorbance reading was made at $570 \mathrm{~nm}$. The values obtained were compared to a glycine standard curve. The total amino acid content was expressed as percentage of the dry matter.

The total soluble sugars and reducing sugars were extracted by water from dry leaves. The determination of soluble reducing sugars followed the technique described by Nelson (1944) using Somogy's and Nelson's reagents. Absorbance readings were performed at $545 \mathrm{~nm}$ and compared to a glucose standard curve. The method described by Dubois et al. (1956) was utilized for the determination of total soluble sugars, by the reaction with phenol and sulfuric acid. Absorbance readings were performed at $545 \mathrm{~nm}$. Results were compared to a glycine standard curve. The total soluble sugars and reducing sugars in the dry mass were expressed as percentages.

The total $\mathrm{N}$ content in the dry matter of leaves was determined by sulfuric digestion and analysis according to specifications presented by Sarruge \& Haag (1974). Results were expressed as grams of nitrogen per $\mathrm{kg}$ of dry mass.

Dry mass of plants were expressed as grams per plant. Plant height corresponded to the distance between soil surface and plant apex. The total number of stalks divided by the number of plants per box was also evaluated. Plants from both cultivars had a 59-day cycle. Grain productivity was determined based on the panicles from all plants that remained in the boxes after being cut and left to dry in full sun. Grains were then manually removed from the panicles and weighed. Data were transformed into $g$ per plant (13\% wet basis).
The results were submitted to analysis of variance and the cultivar means compared by the Tukey test $(P=0.05)$. Means of different levels of $\mathrm{N}$ applied as sidedressing were evaluated by regression analysis. The criterion adopted to select a model was the magnitude of the regression coefficients at the 5\% level.

\section{RESULTS AND DISCUSSION}

There were no influences of cultivar and of the cultivar $\times \mathrm{N}$ level interaction on any of the biochemical variables (Table 1). The $\mathrm{N}$ levels affected all biochemical variables, except urease activity (Table 1). The relative chlorophyll content fitted a quadratic function (Figure 1); as the level of sidedressing $\mathrm{N}$ increased, the relative chlorophyll content also increased, as verified by direct reading on the equipment, up to the peak point, which occurred at the $157 \mathrm{mg} \mathrm{L}^{-1} \mathrm{~N}$ rate. This result corroborates results obtained by Crusciol et al. (2001), who observed that the highest levels of $\mathrm{N}$ available in the soil and the greater uptake of this element increased the pigment content indicating, to a certain extent, that plants did not produce chlorophyll beyond their requirements.

Urease activity was not influenced by application of N (Table 1). Similar results were verified by Cataneo (1989), who observed that nitrogen supplementation in the form of nitrate and urea to bean plants did not change urease activity. At the time of determination (full bloom), the enzyme activity was stabilized, since most of the absorbed urea had already been hydrolyzed by urease, yielding ammonia, which is utilized for amino acid synthesis by the plants.

Table 1 - Relative chlorophyll content in leaves, urease activity, total amino acid content, total sugars and reducing sugars contents in the above-ground part of fall panicum plants, 44 days after emergence, for two cultivars and different sidedressing $\mathrm{N}$ levels.

\begin{tabular}{|c|c|c|c|c|c|}
\hline Causes of variation & $\begin{array}{l}\text { Chlorophyll } \\
\text { (SPAD) }\end{array}$ & Urease activity & Total amino acids & Total Sugars & Reducing sugars \\
\hline & & $\begin{array}{c}\mu \mathrm{g} \mathrm{NH} / \mathrm{g} \text { fresh } \\
\text { mass/minute }\end{array}$ & - - & $\%$ in $\mathrm{DM}$ & 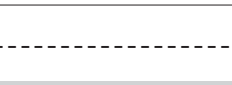 \\
\hline & $-\cdots--1$ & - & --- F Values -. & - & - - - - - \\
\hline Cultivar (C) & $0.37 \mathrm{~ns}$ & $0.12 \mathrm{~ns}$ & $0.16 \mathrm{~ns}$ & $1.22 \mathrm{~ns}$ & $0.02 \mathrm{~ns}$ \\
\hline Sidedressing N (N) & $31.30 * *$ & $1.49 \mathrm{~ns}$ & $20.09 * *$ & $6.42 * *$ & $4.23 * *$ \\
\hline $\mathrm{C} * \mathrm{~N}$ & $1.44 \mathrm{~ns}$ & $0.28 \mathrm{~ns}$ & $2.08 \mathrm{~ns}$ & $1.44 \mathrm{~ns}$ & $0.49 \mathrm{~ns}$ \\
\hline \multicolumn{6}{|l|}{ Sidedressing N } \\
\hline L.R. & $98.21 * *$ & $0.37 \mathrm{~ns}$ & $44.12 * *$ & $11.21 * *$ & $9.09 * *$ \\
\hline Q.R. & $45.01 * *$ & $0.31 \mathrm{~ns}$ & $42.93 * *$ & $17.45 * *$ & $5.09 *$ \\
\hline \multicolumn{6}{|l|}{ Cultivars } \\
\hline AL Tibagi & 30.7 & 0.0017 & 6.61 & 4.16 & 2.56 \\
\hline AL Mogi & 31.1 & 0.0017 & 6.76 & 4.63 & 2.62 \\
\hline $\mathrm{CV}(\%)$ & 6.2 & 6.3 & 16.9 & 28.8 & 39.1 \\
\hline
\end{tabular}

*,**, and ns are, respectively: significant at 5\%,1\% and non-significant by the F test. L.R. = Linear regression. Q.R.= Quadratic regression. 
The total amino acid content fitted a quadratic function (Table 1 and Figure 1), showing a point of maximum at the $134 \mathrm{mg} \mathrm{L}^{-1} \mathrm{~N}$ rate. A similar result was obtained by Mengel \& Kirby (1978), who mentioned that the amino acid content increased considerably in maize, as the amount of available $\mathrm{N}$ increased. Amino acids are derived from glycolysis intermediate compounds, from the citric acid cycle or from the pentoses-phosphate pathway, and $\mathrm{N}$ is incorporated into these pathways via glutamate and glutamine (Nelson \& Cox, 2000). Therefore, the greater the amount of $\mathrm{N}$ available, the greater the amino acid synthesis, but only up to a certain point, above which inhibition occurs, as observed.

Total sugar content and reducing sugar content fitted both quadratic equations (Table 1 and Figure 1). Sugar
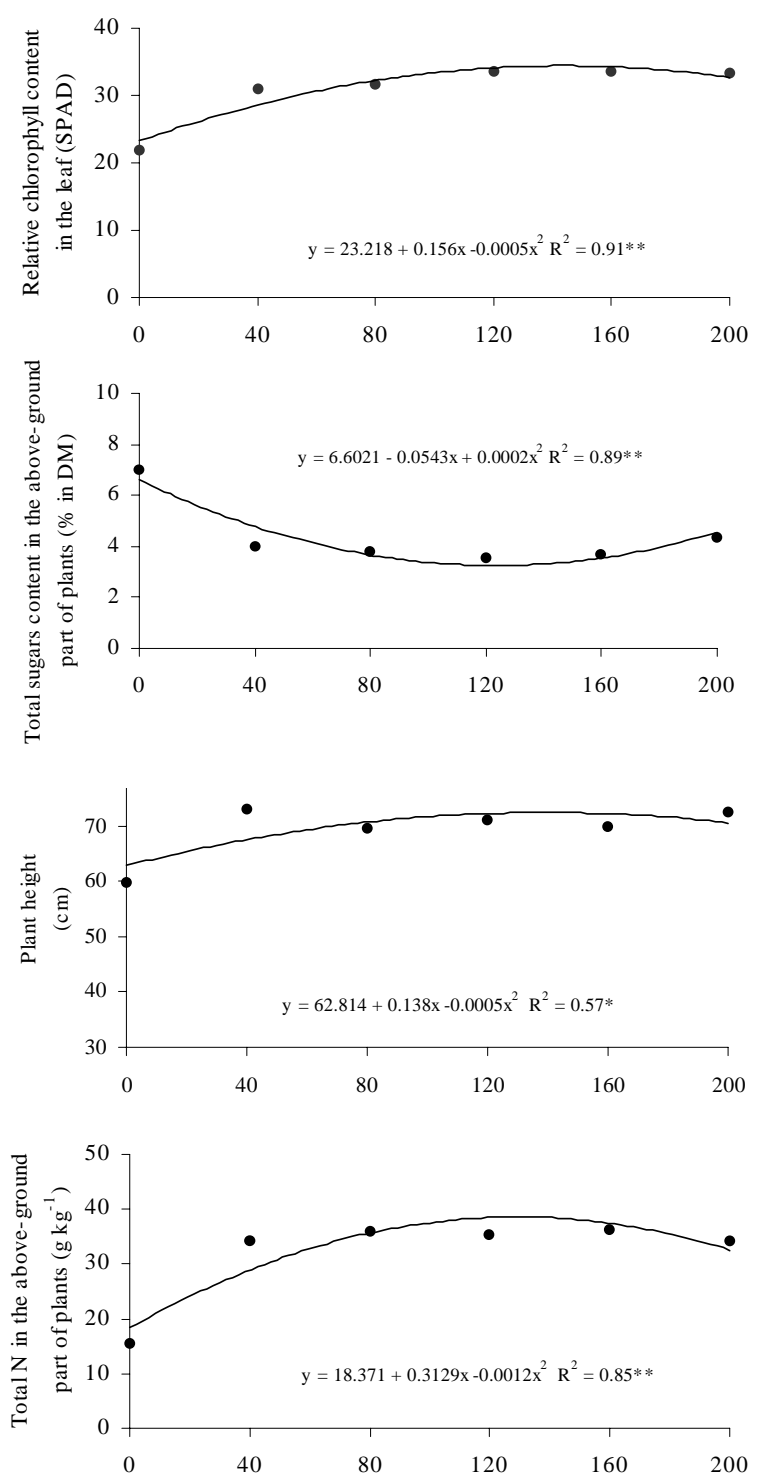

Sidedressing $\mathrm{N}$ levels $\left(\mathrm{mg} \mathrm{L}^{-1}\right)$

Figure 1 - Chlorophyll contents in leaves, total amino acids, total and reducing sugars in the above-ground part, plant height, number of stalks per plant, total $\mathrm{N}$ content in the above-ground part and grain yield of fall panicum plants, mean of two cultivars, as a function of sidedressing $\mathrm{N}$ levels (* and ** are, respectively, significant at $5 \%$ and $1 \%$ ).

Sci. Agric. (Piracicaba, Braz.), v.61, n.1, p.82-87, Jan./Fev. 2004 
Table 2 - Plant height, number of stalks per plant, dry mass, $\mathrm{N}$ total content in the above-ground part and grain yield of fall panicum plants, for two cultivars and different sidedressing $\mathrm{N}$ levels.

\begin{tabular}{|c|c|c|c|c|c|}
\hline Causes of variation & Plant height & Stalks per plant & Dry Mass & Total $\mathrm{N}$ & Grain yield \\
\hline & $\mathrm{cm}$ & & g plant $^{-1}$ & $\mathrm{~g} \mathrm{~kg}^{-1}$ & g plant $^{-1}$ \\
\hline & - & $-\cdots-1$ & -- F Values & - & -........ \\
\hline Cultivar (C) & $6.66 *$ & $0.002 \mathrm{~ns}$ & $0.07 \mathrm{~ns}$ & $0.001 \mathrm{~ns}$ & $0.001 \mathrm{~ns}$ \\
\hline Sidedressing N (N) & $3.40 *$ & $5.27 * *$ & $1.18 \mathrm{~ns}$ & $47.42 * *$ & $1.23 *$ \\
\hline $\mathrm{C}^{*} \mathrm{~N}$ & $2.49 \mathrm{~ns}$ & $2.39 \mathrm{~ns}$ & $0.61 \mathrm{~ns}$ & $2.24 \mathrm{~ns}$ & $0.24 \mathrm{~ns}$ \\
\hline \multicolumn{6}{|l|}{ Sidedressing N } \\
\hline L.R. & $2.45 \mathrm{~ns}$ & $18.62 * *$ & $4.40 \mathrm{~ns}$ & $101.26^{* *}$ & $2.17 *$ \\
\hline Q.R. & $3.14 *$ & $2.64 \mathrm{~ns}$ & $0.47 \mathrm{~ns}$ & $99.52 * *$ & $3.09 \mathrm{~ns}$ \\
\hline \multicolumn{6}{|l|}{ Cultivars } \\
\hline AL Tibagi & $66.7 \mathrm{~b}$ & 1.66 & 4.09 & 31.9 & 2.53 \\
\hline AL Mogi & $72.9 \mathrm{a}$ & 1.65 & 4.22 & 31.9 & 2.54 \\
\hline $\mathrm{CV}(\%)$ & 10.2 & 21.3 & 35.9 & 9.1 & 34.1 \\
\hline
\end{tabular}

The number of stalks per plant was influenced by the application of sidedressing N (Table 2). Data fitted a linear function, showing that the greater the application of sidedressing $\mathrm{N}$, the greater the number of stalks per plant. This can be explained by the increase in vegetative growth and by the promotion of tillering caused by the great amount of available N. These results agree with those by Purcino (1981), who verified vigorous growth and intense green color when this element was supplied, and when other factors were not limiting. However, dry mass of the cultivars did not vary under different nitrogen levels or between cultivars, and no significant interaction occurred between causes of variation, which can be justified by the high coefficients of variation observed (Table 2).

The total $\mathrm{N}$ content in the above-ground part of the plants fitted a quadratic function, showing a point of maximum for total $\mathrm{N}$ content at the $130 \mathrm{mg} \mathrm{L}^{-1} \mathrm{~N}$ rate (Table 2 and Figure 1). Silva et al. (1999) also observed an increasing response in $\mathrm{N}$ content in the above-ground part of bean plants as consequence of sidedressing $\mathrm{N}$ application. Alejo \& Crocomo (1981) observed an increase in total $\mathrm{N}$ content in the above-ground part of sugarcane as the application of urea increased. Maman et al. (1999) also observed an increase in dry matter $\mathrm{N}$ content of a millet hybrid with the application of mineral nitrogen. According to those authors, the likely increase in the velocity of synthesis of nitrogen compounds occurred because of the greater $\mathrm{NH}_{4}^{+}$availability, resulting from urea hydrolysis.

Since the appropriate total $\mathrm{N}$ contents in the above-ground part of fall panicum plants is unknown, the critical level for rice was utilized for comparison (Malavolta et al., 1980; Cantarella et al., 1997). With the exception of the treatment without $\mathrm{N}$ (control), which had a content below the critical level $\left(27 \mathrm{~g} \mathrm{~kg}^{-1}\right)$, plants of all treatments involving $\mathrm{N}$ applications presented adequate levels of this nutrient at blooming time, in the aerial part. This probably occurred because plant needs were supplied by the treatments containing $\mathrm{N}$.

Yield fitted a linear function as sidedressing $\mathrm{N}$ increased, grain yield also increased (Table 2). Several papers emphasize the response of different crops, for example, millet, rice, wheat, maize, and bean, to sidedressing N application (Costa et al., 1983; Maman et al., 1999; Silva et al., 1999; Rodrigues et al., 2000; Silva et al., 2000; Soratto et al., 2000; Ferreira et al., 2001; Soratto et al. 2001). However, Furuhashi (1995), studying the effect of rates and seasons of nitrogen sidedressing for fall panicum, concluded that the sidedressing $\mathrm{N}$ application did not influence grain productivity. The absence of a response by the crop to the application of nitrogen can be explained by the fact that fall panicum was grown in succession to black velvet bean, a legume utilized as a green manure with high atmospheric $\mathrm{N}_{2}$ fixation ability, and according to Quaggio \& Raij (1997), this area was characterized as having low response to $\mathrm{N}$.

Finally, the greatest differences observed for the evaluated variables were verified between the treatment without nitrogen application (control) and the smallest rate of this nutrient $\left(40 \mathrm{mg} \mathrm{L}^{-1}\right)$, while the differences verified between the other applied rates were smaller (Figure 1).

\section{CONCLUSIONS}

The fall panicum cultivars of this experiment had similar performance with regard to the evaluated variables, as a response to sidedressing nitrogen application. The application of $\mathrm{N}$ rates to the fall panicum crop pro- 
vided increases in the contents of relative chlorophyll, total amino acids, total nitrogen, and in plant height, and a reduction in dry matter sugars, up to the interval between 120 and $160 \mathrm{mg} \mathrm{N} \mathrm{L}^{-1}$. Tillering and grain yield experienced a linear increase with the application of $\mathrm{N}$. Nitrogen fertilization did not affect dry matter yield.

\section{REFERENCES}

ALEJO, N.O.; CROCOMO, O.J. Biochemical and physiological aspects of sugarcane. II. Effect of $\mathrm{NO}_{3}^{-}-\mathrm{N}, \mathrm{NH}_{4}^{+}-\mathrm{N}$ and urea-N on carbohydrate level and growth of cv. NA56-79. Energia Nuclear na Agricultura, v.3, p.137-151, 1981

CANTARELLA, H.; RAIJ, B. van; CAMARGO, C.E.O. Cereais. In: RAIJ, B. van; CANTARELA, H.; QUAGGIO, J.A.; FURLANI, A.M.C. Recomendações de adubação e calagem para o Estado de São Paulo. 2.ed. Campinas: IAC, 1997. p.43-71, (Boletim Técnico, 100).

CATANEO, A.C. Efeitos de fontes de nitrogênio (N-Uréia e N-Nítrico) na atividade de urease (E C 3.5.1.5), nos níveis de compostos nitrogenados e de carboidratos em feijoeiro (Phaseolus vulgaris L.) cultivar Carioca, cultivado em solução nutritiva. Botucatu: UNESP/IB, 1989. 96p. (Dissertação - Mestrado)

CLARK, R.B. Physiology of cereals for mineral nutrient uptake, use and efficiency. In: BALIGAR, V.C.; DUNCAN, R.R. (Ed.) Crops as enhancers of nutrient use. San Diego: Academic Press, 1990. p.131209.

COSTA, N.P.; GOMES, A.S.; PESKE, S.T.; POPINIGIS, F.; ZONTA, E.P. Influência da adubação nitrogenada sobre o vigor e conteúdo de proteínas de sementes de quatro cultivares de arroz irrigado. Revista Brasileira de Sementes, v.5, p.31-41, 1983

CRUSCIOL, C.A.C.; ANDREOTTI, M.; LIMA, E.V.; FURLANI JR., E.; NAKAGAWA, J. Teores de nutrientes, concentração de clorofila e produtividade de grãos do feijoeiro em função da adubação nitrogenada de semeadura ou em cobertura. Revista de Agricultura, v.76, p.101114,2001

DUBOIS, M.; GILLES, K.A.; HAMILTON, J.K.; REBERS, P.A.; SMITH, F. Colorimetric method for determination of sugars and related substances. Analytical Chemistry, v.28, p.350-356, 1956.

FERREIRA, A.C.B.; ARAÚJO, G.A.A; PEREIRA, P.R.G.; CARDOSO, A.A. Características agronômicas e nutricionais do milho adubado com nitrogênio, molibdênio e zinco. Scientia Agricola, v.58, p.131-138, 2001.

FURUHASHI, S. Efeito de doses e de época de aplicação de nitrogênio na cultura do painço em sucessão a mucuna-preta. Jaboticabal: UNESP/ FCAV, 1995. 31p. (Monografia - Graduação)

HOGAN, M.E.; SWIFT, I.E.; CONE, J. Urease assay and ammonia release from leaf tissues. Phytochemistry, v.22, p.663-667, 1983.

KABAT, E.A.; MAYER, M.M. Experimental immunochemistry. Springfield: C.C. Thomas, 1967. p.560-563.

LIMA, E.V.; CAVARIANI, C.; LIMA, P.L.; CRUSCIOL, C.A.C.; NAKAGAWA, J.; VILLAS BOAS, R.L. Qualidade fisiológica de sementes de painço (Panicum dichotomiflorum mix.) em função do tempo de mistura com o superfosfato triplo. Cultura Agronômica, v.9, p.177$189,2000$.

MALAVOlTA, E. ABC da Adubação. São Paulo: Ceres, 1979. p.26-30: Adubos nitrogenados

MALAVOLTA, E.; DAMIÃO FILHO, C.F.; VOLPE, C.A.; MACHADO JR., G.R.; VELHO, L.M.S.; ROSA, P.R.F.; DE LAURENTIZ, S. Deficiências e excessos minerais no feijoeiro (Phaseolus vulgaris L., cv. Carioca). Anais da ESALQ, v.37, p.701-718, 1980.
MALAVOLTA, E.; VITTI, G.C.; OLIVEIRA, S.A. Avaliação do estado nutricional das plantas: princípios e aplicações. 2.ed. Piracicaba: POTAFOS, 1997. 319p.

MAMAN, N.; MASON, S.C.; GALUSHA, T.; CLEGG, M.D. Hybrid and nitrogen influence on pearl millet production in Nebraska: yield, growth, and nitrogen uptake, and nitrogen use efficiency. Agronomy Journal v.91, p.737-743, 1999.

MENGEL, K.; KIRBY, E.A. Principles of plant nutrition. Bern: International Potash Institute, 1978. 593p.

MINOLTA CAMERA. Manual for chlorophill meter SPAD 502. Osaka: Minolta Radiometric Instruments Divisions, 1989. 22p.

NELSON, N. A photometric adaptation of the Somogyi method for determination of glucose. Journal Biological Chemistry, v.153, p.375$380,1944$.

NELSON, D.L.; COX, M.M. Lehninger principles of biochemistry. 3.ed. New York: Worth Publishers, 2000. 1152p.

OLIVEIRA, I.P.; ARAÚJO, R.S.; DUTRA, L.G. Nutrição mineral e fixação biológica de nitrogênio. In: ARAUJO, R.S.; RAVA, C.A.; STONE, L.F.; ZIMMERMANN, M.J.O. Cultura do feijoeiro comum no Brasil. Piracicaba: Potafós, 1996. p.169-221.

PURCINO, A.A.C. Nitrogênio, correção e adubação do solo. Informe Agropecuário, v.7, p.16-20, 1981

QUAGGIO, J.A.; RAIJ, B. van. Produtividade esperada. In: RAIJ, B. van; CANTARELA, H.; QUAGGIO, J.A.; FURLANI, A.M.C. Recomendações de adubação e calagem para o Estado de São Paulo. 2.ed. Campinas: IAC, 1997. p.13-14, (Boletim Técnico, 100).

RAIJ, B. van; ANDRADE, J.C.; CANTARELLA, H.; QUAGGIO, J.A. (Eds.). Análises Químicas para avaliação de fertilidade de solos tropicais. Campinas: IAC, 2001. 284p.

RODRIGUES, O.; DIDONET, A.D.; GOUVEIA, J.A.; SOARES, R.C. Nitrogen translocation in wheat inoculated whit Azospirillum and fertilized wih nitrogen. Pesquisa Agropecuária Brasileira, v.35, p.1473$1481,2000$.

SARRUGE, J.R.; HAAG, H.P. Análises químicas em plantas. Piracicaba: ESALQ, 1974. 56p.

SILVA, T.R.B.; SORATTO, R.P.; CHIDI, S.N.; ARF, O.; SÁ, M.E.; BUZETTI, S. Doses e épocas de aplicação de nitrogênio em cobertura na cultura do feijoeiro de inverno. Cultura Agronômica, v.9, p.1-17, 2000.

SILVA, T.R.B.; SORATTO, R.P.; SILVA, L.C.; DOURADO, M.C.; ALVES M.C. Diferentes doses e épocas de aplicação de N, e sua influência na matéria seca das plantas e $\mathrm{N}$ total em folhas de feijão. Cultura Agronômica, v.8, p.117-129, 1999.

SORATTO, R.P.; SILVA, T.R.B.; ARF, O.; CARVALHO, M.A.C. Níveis e épocas de aplicação de nitrogênio em cobertura no feijoeiro irrigado em plantio direto. Cultura Agronômica, v.10, p.89-99, 2001.

SORATTO, R.P.; SILVA, T.R.B.; CHIDI, S.N.; ARF, O.; SÁ, M.E.; BUZETTI, S. Feijoeiro irrigado e aplicação de nitrogênio em cobertura e molibdênio via foliar. Cultura Agronômica, v.9, p.115-132, 2000.

TURLEY, R.H.; CHNG, T.M. Physiological responses of barley leaves to foliar applied urea-ammonium nitrate. Crop Science, v.26, p.987-993, 1986.

WEATHERBURN, M.W. Phenol-hypochlorite reaction for determination of ammonia. Analytical Chemistry, v.39, p.971-974, 1967.

Received December 05, 2002

Accepted October 23, 2003 